$\begin{array}{r}\text { ANGIELS } \\ \text { NEW PERSPECTUE5 } \\ \hline\end{array}$ ANELOPHINE WORLD

\section{Angles}

New Perspectives on the Anglophone World

11 | 2020

Are You Game?

\title{
From Cardboard Settings to Ludo-anthropological Experiences: The Failures and Successes of Victorian London's Adaptations in Video Games
}

\section{Nicolas Sigoillot}

\section{(2) OpenEdition}

Journals

Electronic version

URL: https://journals.openedition.org/angles/2818

DOI: $10.4000 /$ angles.2818

ISSN: 2274-2042

Publisher

Société des Anglicistes de l'Enseignement Supérieur

\section{Electronic reference}

Nicolas Sigoillot, "From Cardboard Settings to Ludo-anthropological Experiences: The Failures and Successes of Victorian London's Adaptations in Video Games", Angles [Online], 11 | 2020, Online since 01 November 2020, connection on 07 June 2022. URL: http://journals.openedition.org/angles/2818 ; DOI: https://doi.org/10.4000/angles.2818

This text was automatically generated on 7 June 2022.

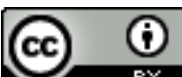

Angles est mise à disposition selon les termes de la Licence Creative Commons Attribution 4.0 International. 


\title{
From Cardboard Settings to Ludo- anthropological Experiences: The Failures and Successes of Victorian London's Adaptations in Video Games
}

\author{
Nicolas Sigoillot
}
"Oh, splendid, you're here to murder me [...]" "I'm not here to kill you." "Then what's your game?"

1 Lady Hattaway, a powerful opponent in the video game Assassin's Creed Syndicate (Ubisoft 2015), addresses these words metanarratively to Jacob, the player's avatar. As the title of Assassin's Creed Syndicate implies, the game consists in assassinating enemies. What has made this series of games popular is its impressive rendition of the geographical and historical context in which they take place. The Syndicate episode is set in London at the end of the $19^{\text {th }}$ century - in 1868 , to be precise. The Victorian setting has always been popular in video games because the period is both modern and intriguing, close to our times but still shrouded in a strong mythos. The popularity of the Victorian setting has also been raised by the steampunk artistic movement which emerged in the 1980s which blends elements of both science fiction and magic to an aesthetic of the industrial revolution (Vandermeer 2011). Some of the most popular games taking place in Victorian London, or in a fictional city inspired by it, include: The Chaos Engine (Renegade Software 1993), MediEvil 2 (Sony Computer Entertainment 2000), Alice: Madness Returns (Spicy Horse 2011), Assassin's Creed Syndicate (Ubisoft 2015), The Order 1886 (Ready at Dawn 2015), Bloodborne (FromSoftware 2015) and Vampyr (Dontnod Entertainment 2018). Video games enable the player to explore their fictional settings in a manner that no other medium or form of art allows. Even if a painting or a movie representing a specific historical setting provoke different subjective reactions in different people, they still represent the same item for each viewer. A video game, on 
the other hand, thanks to its unique input/output logic associated to a predetermined gameworld, should never offer the same experience to anyone because what the player sees is triggered by his/her own actions. The (musical and pictorial) artistic components of a video game are subordinated to the actions undertaken by the player. In other words, the player experiences the gameworld by entering a separate space on which he/she exerts a form of power through his avatar and/or his controls.

2 Thanks to the graphic improvements of video games over the past two decades, the fidelity and authenticity of the games' renditions of real-life places such as Victorian London have been examined by historians such as Robert Whitaker, a specialist of Modern Britain and Professor of History at Collin College. Critical literature has been produced on whether big budget video games can be used in school lessons to help students understand or picture some historical or geographical areas through a medium which they may find more appealing. For example, Romain Vincent, a PhD candidate is undertaking research on this field and devoted a blog, https:// jeuvideohistoire.com/, to his research, further suggesting how historical video games can be used pedagogically in classes for all levels. Due to the popular appeal of video games, it would give students the possibility to experience the object of study in a unique way (Karsenti 2019). However, this approach divides cultural historians, as some question the legitimacy of such a medium. Marc Marti, professor at Nice Sophia Antipolis University, thus points to the relationship between the game narrative and the historical narrative and how the representation of history in games contributes to a fictionalisation of history which then contributes to a national narrative (Marti 2018). For Marti, video games are more interesting from a historiographical standpoint than from a historical one.

Cultural studies as well as humanities in their broader sense could offer a different point of view on this debate. From asking: "is this game faithful to history?" one could move to the more anthropological question of the uses of depicting a certain environment, accurately or not. What would be the effects of the representation of child labour in a game on a player, for instance? What use is this representation in terms of gameplay? How are gameplay and representation of history linked? What could narratology, anthropology and history bring to game design? And finally, is the opposite true? Could video games develop useful skills for cultural studies in their users, notably through the use of methods for the study of anthropology such as fieldwork and ethnography?

In this paper, I compare the representation of Victorian London in two video games: Assassin's Creed Syndicate (Ubisoft 2015) and The Order 1886 (Ready at Dawn 2015). Both constitute a solid basis for a comparative approach because they take place in the same setting and were released in the same year while presenting a fair number of differences. Assassin's Creed Syndicate is a stealth-action game released on various platforms (Xbox One, PlayStation 4, PC) which claims to remain faithful historically to its setting and puts the player in the role of two assassin twins acting covertly to get rid of the secret society of the Templar that dominate London economically and politically. Assassin's Creed Syndicate thus presents a uchronic story of an invisible war that realistically could have been taking place in London. The Order 1886, on the other hand, is a third-person shooting game which takes place, as its name suggests, in 1886. It was released on only one platform (PlayStation 4) and never claimed to be entirely faithful to history as it places the player in the role of a member of the Knights of the Round 
Table, an organisation aimed at fighting against mythological creatures such as werewolves and vampires in Victorian London. The games also differ in that Assassin's Creed Syndicate is part of a long series of games (Assassin's Creed), while The Order 1886 is a standalone game.

The game-design philosophies of the two games are very distinct. Assassin's Creed Syndicate is an open-world game, leaving nearly its entire environment accessible to the player from the beginning, placing exploration and experimentation at the centre of its device with what one calls an 'emergent gameplay', i.e. a set of situations resulting from the ability of the player to approach problems in different manners thanks to a set of simple rules. The way the game "plays" is thus defined by the player's actions. If the player needs to climb a tower, he or she can do it either through the use of a grappling hook, through normal climbing, or by going in the tower and using the stairs. The variety of possibilities offered to the player is key, even though these are not explicitly suggested to them.

6 The pacing of the narrative is also different in both games. In Assassin's Creed Syndicate, the player is free to put the plot on hold and undertake other quests through London at any moment. On the other hand, The Order 1886 is a plot-driven game where the players are directed in a predetermined order and cannot escape the unfolding of events which are presented to them.

7 My aim, through a transdisciplinary comparison of these two games will be to show the relevance of the study of video games to both cultural and historical studies. Video games, I will argue, represent a virtual new-frontier that enables players to take up the role of an anthropologist through a fictional participant observation in a defined setting. According to Philipp Schweighauser, Professor of American and general literatures at the University of Basel, the gaming experience generates a dual reality, the fictional universe and the player's alter-ego in this universe. The fictional gameworld creates a real space in which the player's understanding of his/her environment is strong because it becomes real to him/her, the player is himself/herself (with limitations imposed by the game) while stepping out of his/her physical reality (Schweighauser 2009). A transdisciplinary comparison of The Order 1886 and Assassin's Creed Syndicate ultimately will allow me to propose a model of two different approaches to player participation in the exploration of historical settings in video games.

\section{The Order 1886: Victorian London as a Setting, but Nothing More}

8 The Order 1886 is a third-person shooter game. It might be classified more precisely as a cover-shooter genre because at the core of the game's design is the ability of the player's character to hide behind elements of the environment. The camera is set very close to the main character, off-centre, as if the player were watching above the character's shoulder. The game has a clearly cinematic style, with frequent cutscenes during which the player cannot interact at all. To maintain the attention of the player, the game relies on the use of Quick Time Events (QTEs) during which the player has a very limited amount of time to execute a command when prompted on the screen. In The Order 1886, there are only three types of commands: pressing a specific button on the game controller, or rapidly mashing or holding down a specific button (Figure 1). QTEs are somewhat controversial in video games: they can have two different 
interpretations and depend heavily on the choices the developers made in incorporating them to their game-design. They can easily ruin immersion by not requiring complex inputs and can lead to an impression of playing interactive movies; or they can offer more immersion by creating stressful moments in cutscenes, making the player feels the same amount of stress as his/her character. Overall, critics agreed that The Order 1886 failed at involving the player through this process. The display of a big triangle on the screen when the character needs to open a door in a cutscene, which makes the game belong to a hybrid genre between movies and games, led it, in addition to its relative shortness, to receive mixed reviews with an average Metacritic score of 63 out of 100 , with reviews ranging from 95 to $20 .{ }^{1}$ The combination of two genres (movie and game) requires a certain balance to work in an immersive manner. In the case of QTEs, making them challenging or involving different outcomes to a scene rather than just displaying a 'game over' message on the screen when the player fails to execute them can be a solution. Games such as Heavy Rain (Quantic Dream 2010) or Shenmue (SEGA 1999) were critically praised for their smart use of QTEs. For movies which adapt video games, the system works similarly: simply porting a game setting and plot doesn't work, often leading to poorly rated movies when the adaptation is not a standalone movie, requiring knowledge of the game to be appreciated. Movies such as Mortal Kombat (Anderson 1995) or Max Payne (Moore 2008) are good examples of such failures.

Figure 1: An example of Quick Time Event (QTE)

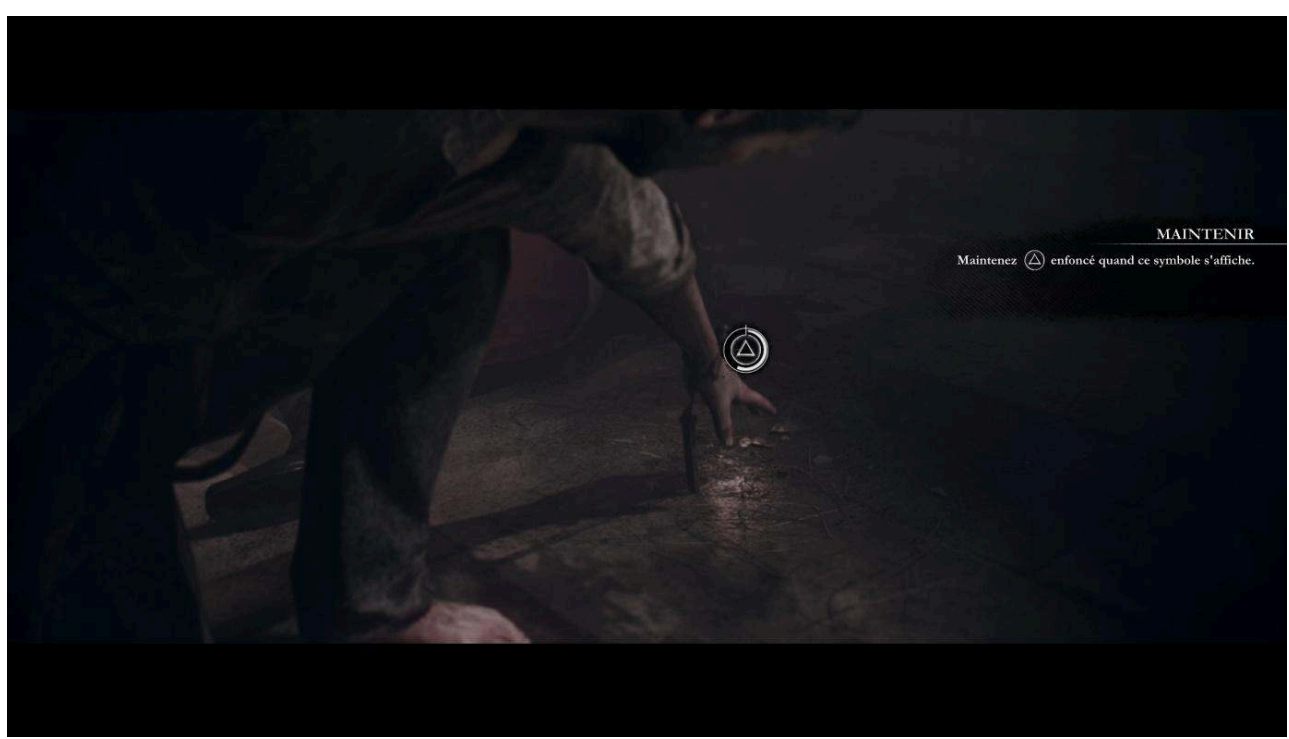

Here, the player has to keep pressing on the triangle to pick up an item during a cutscene. Credits: The Order 1886, Ready at Dawn.

9 The Order 1886 is set in a fictional London that belongs more to the science-fiction steampunk genre than to a realistic neo-Victorian interpretation of the city. The plot of the game involves the Order of the Knights of the Round Table, a not-so-secret organisation that fights against an illness that spreads through the city, making people mad and turning some of them into werewolves. It is not explained how secret the Order is, but it seems that most of the policemen the player encounters know them. The playable character is Sir Galahad. Three other knights are there to help him 
through his quest: Lady Igraine, his trainee, Sir Percival, his mentor, and the Marquis de La Fayette, an indomitable French seducer.

The Victorian city is a setting in the game which never really offers gameplay opportunities. Even though the game possesses excellent graphics and the realism of the scenery is impressive, London is rarely visible in its entirety and the player can only visit the interiors of buildings and underground sewers. The Victorian setting is shown through scraps of newspapers, props and the characters' dress and appearance. Sometimes, the player wanders through streets that look realistic and convincing, but this design never contributes to the gameplay itself (Figure 2).

Figure 2: The rendition of a street in Victorian London in The Order 1886

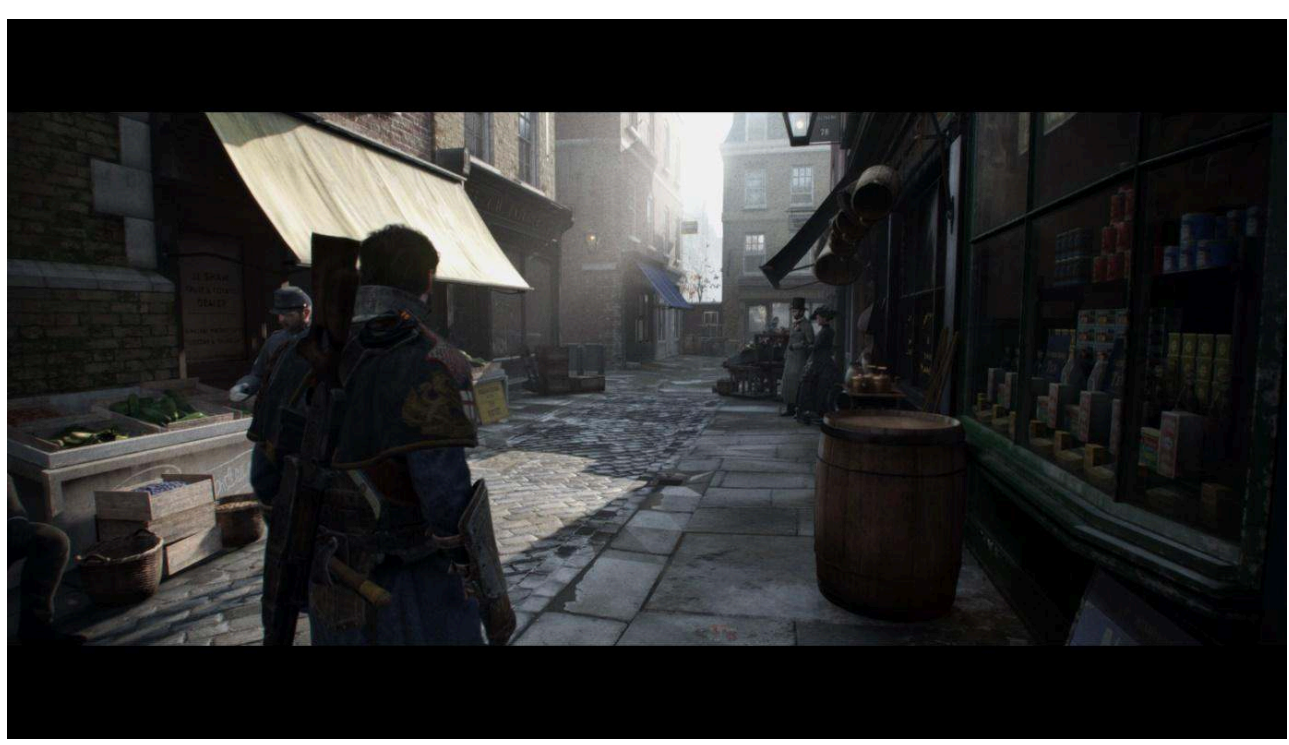

Credits: The Order 1886, Ready at Dawn.

11 The choice of the setting is revealing despite its uselessness for gameplay. Even though the director of the game, Ru Weerasuriya, claims the game does not belong to the steampunk genre (O'Rourke 2014), it possesses all its typical qualities. Jeff Vandermeer, who specialises in this genre, defines steampunk humorously:

STEAMPUNK = Mad Scientist Inventor [invention (steam $\mathrm{x}$ airship or metal man / baroque stylings) $\mathrm{x}$ (pseudo) Victorian setting] + progressive or reactionary politics $\mathrm{x}$ adventure plot. (Vandermeer 2011)

The Victorian setting is a key in the steampunk aesthetic in which the game revolves. The Order 1886 is a grim game with a dark plot: the first act consists in chasing rebels against the British Empire and werewolves. The rebels seem to have made the United India Company their main target and Galahad and his clique must defend the Company, no doubt inspired by the historical East India Company which was dissolved in 1874 . The second act has a convoluted storyline. Eventually Galahad discovers the rebels are right, and that the United India Company brings vampires into the United Kingdom and is assisted by one prominent member of the Order of the Knights of the Round Table. Galahad, after being expelled from the Order because of the machinations of the traitor in its midst, decides to side with the rebels and their leader, the steamy Lakshmi, fighting against the United India Company and the traitor. The game ends on a 
panoramic shot of London with Galahad looking over the scene and talking with Lakshmi; Galahad mentions his imminent departure from the Kingdom.

The game uses the Victorian setting to reinforce the dark atmosphere. The game takes place mostly at night, in dark streets lit by gaslights. Gothic elements such as werewolves and vampires typical not only of the steampunk genre but of Victorian culture contribute to the frightening atmosphere of the game. The game rewrites history, making Jack the Ripper the werewolf at the head of the United India Company. The presence of advanced technology explains why the game belong to the steampunk genre. The Knights of the Round Table use radios to talk with each other during missions; they also use thermite and electric arc rifles, two fictional weapons (see video extract below).

This media file cannot be displayed. Please refer to the online document http:// journals.openedition.org/angles/2818

These weapons are the fruit of the inventor Nikola Tesla, whose name is that of the famous inventor born in the Austro-Hungarian empire in 1856, who is supposedly at the service of the Order but who is actually a member of the rebellion. The game occasionally presents documents to the player to give him/her a sense of realism (Figure 3). Even though those documents are unauthentic, some efforts were made by the development team to make them feel realistic; unfortunately, these documents seldom appear in the game.

Figure 3: A realistic flyer found in the game

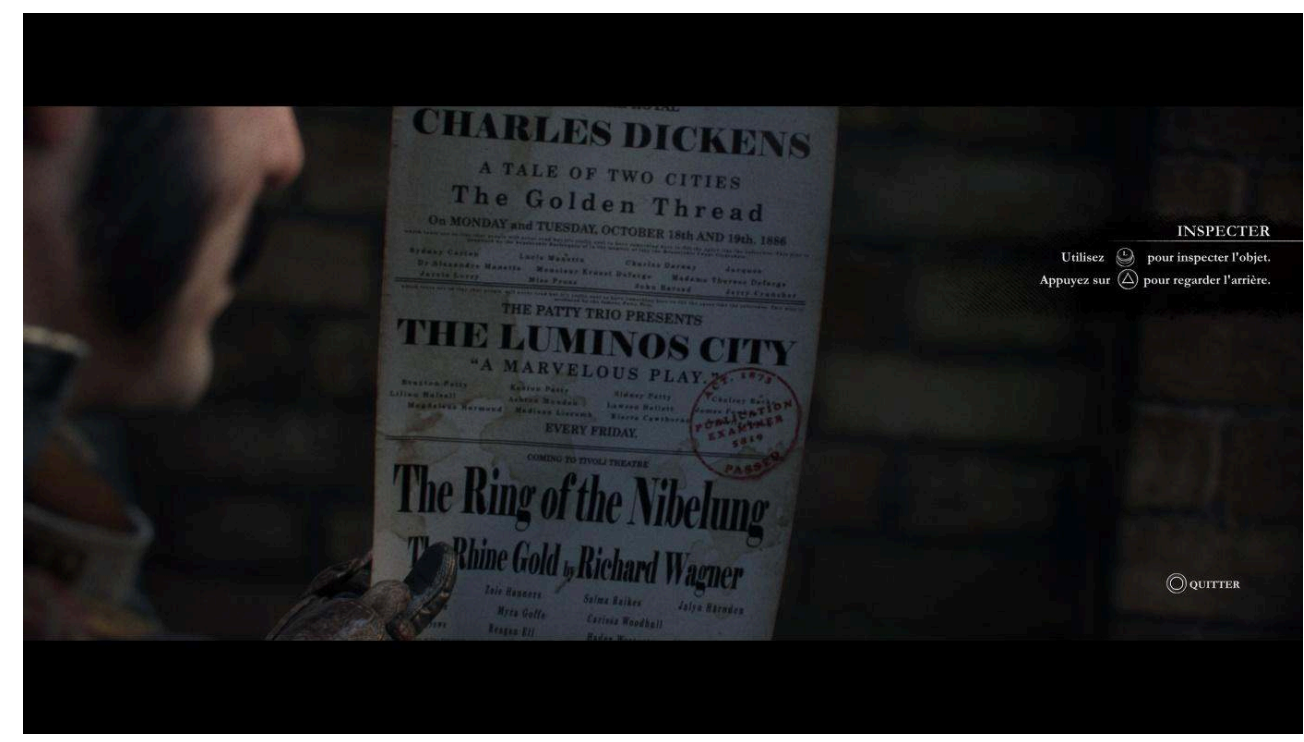

Credits: The Order 1886, Ready at Dawn.

As Cristopher Byrd summed up in The Washington Post, "although the storyline invokes weighty subjects like colonization and socioeconomic inequality, it fails to address these topics in any substantive way" (Byrd 2015). Indeed, the presence of the United India Company, the cruel role played by the Empire, and the atmosphere of social revolt (anarchists are frequently mentioned in-game), the dirty muddy streets and the smoked-filled sky are omnipresent, but never addressed. As such, the game seems to appeal more to the collective imaginary built around the Victorian era than around 
reality. This is symptomatic of the issue raised by Marc Marti in his article on the Spanish Civil war and its representations which sometimes fall into a fictionalization of history for the sake of creating a national memory (Marti 2018).

The Order 1886 is thus frustrating for a player who desires to know more about, or to immerse himself or herself in, Victorian London. The game's narrative techniques are more akin to a cinematographic culture rather than to a ludic culture. Whether the player is a 'completionist' or a casual player, an academic or someone with no knowledge whatsoever of the Victorian era, his or her experience will be the same, whatever the player's intentions (anthropological, historical, or casual). The horror shooter genre to which the game belongs makes the gloomy and dirty state of Victorian London's streets appear as something inherent to the genre of the game rather than to the period itself. The Order 1886's approach to history could be summed up as an aesthetic or cinematic approach.

\section{Assassin's Creed Syndicate: Immersing the Player in a Seemingly Authentic 1868 London}

Assassin's Creed Syndicate is part of a series of more than twenty games that each take place during a specific and highly identifiable historical, geographical and cultural era. The following chart sums up the main games of the series in order of publication in order to gain a sense of the place of Assassin's Creed Syndicate in the series:

\begin{tabular}{|c|c|c|c|c|}
\hline $\begin{array}{l}\text { Release } \\
\text { Date }\end{array}$ & Game & Main Location(s) & Period & Cultural Landmark \\
\hline 2007 & Assassin's Creed & $\begin{array}{l}\text { Jerusalem, Acre, } \\
\text { Damascus }\end{array}$ & $\begin{array}{l}\text { End of } 12^{\text {th }} \\
\text { century }\end{array}$ & Third Crusade \\
\hline 2009 & Assassin's Creed II & Venice, Rome, Florence & $\begin{array}{l}\text { End of } 15^{\text {th }} \\
\text { century }\end{array}$ & Italian Renaissance \\
\hline 2012 & $\begin{array}{l}\text { Assassin's Creed } \\
\text { III }\end{array}$ & $\begin{array}{l}\text { Boston, New York, the } \\
\text { Frontier }\end{array}$ & $1754-1783$ & American Revolution \\
\hline 2013 & $\begin{array}{l}\text { Assassin's Creed } \\
\text { IV: Black Flag }\end{array}$ & $\begin{array}{l}\text { Caribbean islands and } \\
\text { cities }\end{array}$ & 1715 & Golden Age of Piracy \\
\hline 2014 & $\begin{array}{l}\text { Assassin's Creed } \\
\text { Unity }\end{array}$ & Paris & 1789 & French Revolution \\
\hline 2015 & $\begin{array}{ll}\text { Assassin's } & \text { Creed } \\
\text { Syndicate } & \end{array}$ & London & 1868 & Victorian Era \\
\hline 2017 & $\begin{array}{l}\text { Assassin's Creed } \\
\text { Origins }\end{array}$ & Alexandria & $49 \mathrm{BC}$ & $\begin{array}{l}\text { Ptolemaic Egypt, before } \\
\text { the Roman conquest }\end{array}$ \\
\hline 2018 & $\begin{array}{ll}\text { Assassin's } & \text { Creed } \\
\text { Odyssey } & \end{array}$ & $\begin{array}{l}\text { Different cities and } \\
\text { locations in Ancient } \\
\text { Greece }\end{array}$ & $431 \mathrm{BC}$ & Peloponnesian War \\
\hline
\end{tabular}


At first glance, the series aims at offering very diverse contexts to its players, a variety justified by a simple plot device. The story takes place in the present, with contemporary members of the Assassin's secret society exploring the memories of previous assassin members around the world throughout the ages thanks to a technology known as "Helix". This is a pretext, as only a small fraction of the game occurs in the present. In Assassin's Creed Syndicate, the player is unable to play in the present time and is just a spectator of the events unfolding; most of the gameplay consists in wandering about in London in 1868.

19 This leads to an interesting concept from a ludo-narrative point of view. The player will effectively play the roles of Jacob and Evie Frye, two assassins in Victorian London. But he or she is actually impersonating the Helix user who remains nameless in the game. This creates two diegetic environments which serve to tighten the relation between the player and the assassin twins whilst still setting the game in our present times, creating another identification mechanism between the player and the Helix user. These identification devices, both to the characters of the Victorian period and to the current day assassin exploring his/her forebears' memories, make the player an explorer of the Victorian period because it places him/her in the role of an explorer in the game.

One could thus explore the game from an explorer's, or even an anthropologist's point of view, as suggested by Kiri Miller, an ethnomusicologist at Brown University, in an article about the Grand Theft Auto video game series. In her article, she shows how "players move beyond tourism to collaborative complicity with the avatar" (Miller 2008). Assassin's Creed's gameplay is similar to Grand Theft Auto, sharing the same documentary practice, while differing from other classic historical fictions since, in video games, its audience can interact with the recreated historical surroundings. Miller explains that the player adopts the standpoint of an ethnographer when visiting gameworlds (Miller 2008). This analysis functions well in the context of Assassin's Creed Syndicate with its exploration mechanics at the core of the gameplay.

21 The game is an open world with two main mechanisms to motivate the player to explore it. The first is the defining of objectives in an emergent way: it is the environment itself that provides clues to the player. Thanks to the game design, these clues will incite the player to set goals by himself/herself and to experiment with various interactions within his/her environment. The second mechanism is the defining of set objectives by the plot: to progress through the story the player has to accomplish specific objectives.

The emergent gameplay mechanism is what will set the player in the position of an anthropologist via the need to develop an observational attitude. For example, in Assassin's Creed Syndicate, to find what to do in London, the player needs to climb tall buildings or monuments, called viewpoints (Figure 4). From these vantage points, the game will show points of interests that will, from this time onwards, appear on the map (Figure 5). 
Figure 4: Finding objectives from a viewpoint, here from the top of Big Ben

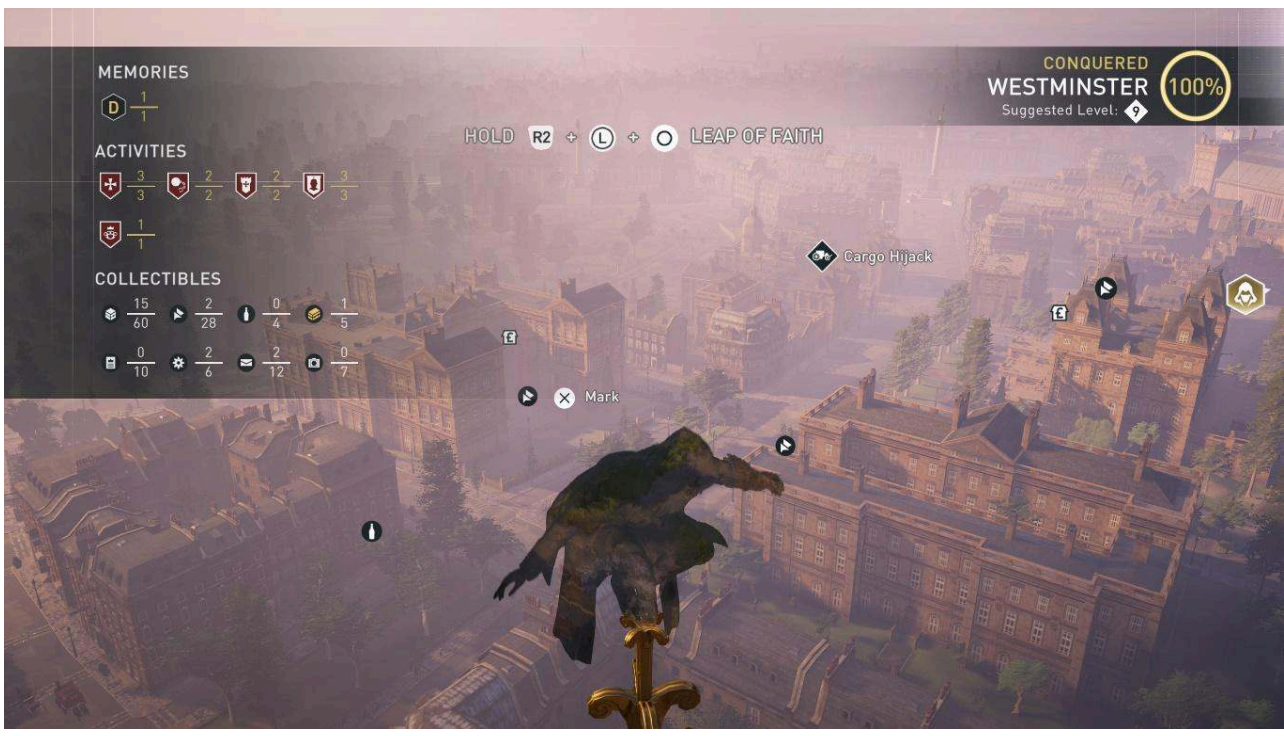

Credits: Assassin's Creed Syndicate, Ubisoft

Figure 5: The game map annotated with the different objectives discovered by the player. Here around St Paul's Cathedral

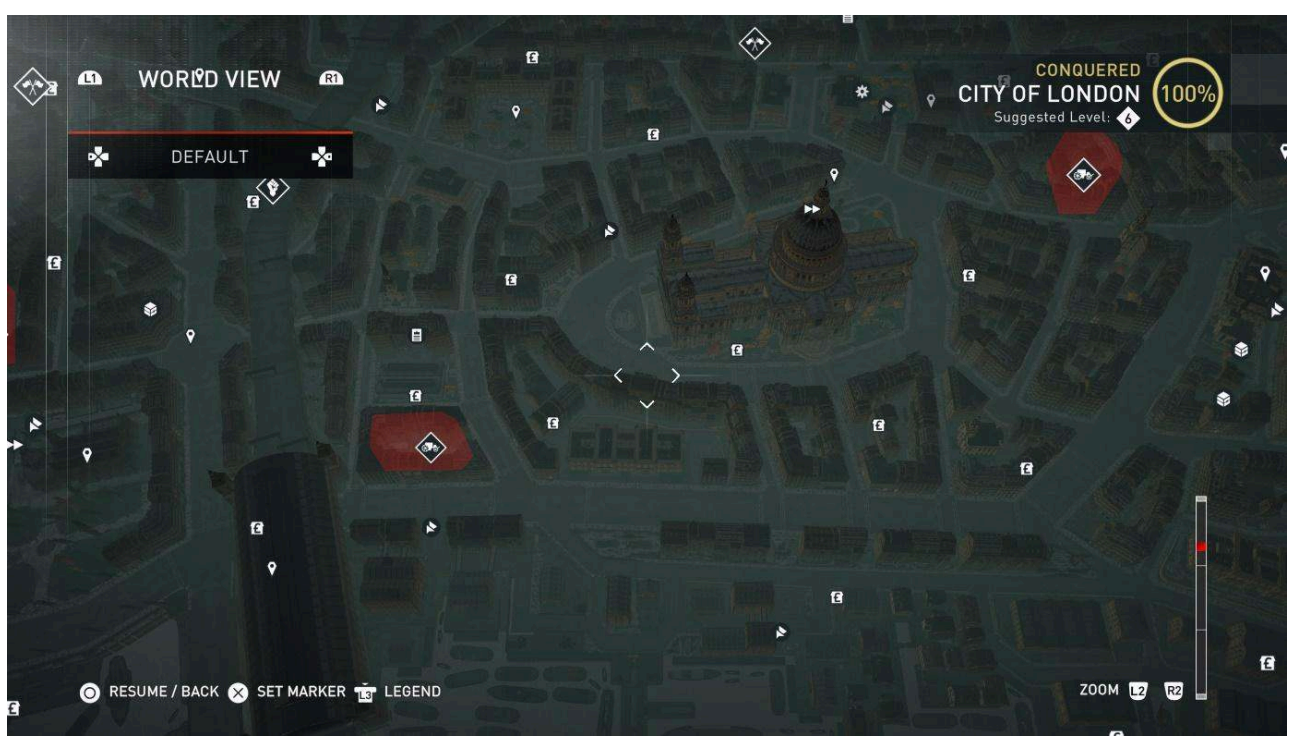

Credits: Assassin's Creed Syndicate, Ubisoft

23 For example, to know what to do, the player will have to climb Big Ben to locate a highranking member of the rival organisation, the Templars. From this point, he or she will be able to assess the quickest way to reach and eliminate the target. To eliminate his/ her target, the player will have to use the field to his/her advantage, first by climbing one of the tallest buildings of the location, to spot how the enemies move around their territory. Then, he/she will have to visit the location, find a way to intervene and remove his/her target without being seen. Stealth is encouraged through the game because if the player character is invisible, he has the ability to kill his foe in one deadly strike. If the player character is discovered by his enemies, he will have to fight first in a single combat and then in a mass combat since the foe will call his allies to the 
rescue. This prioritizing of stealth also benefits exploration because it will incite the player to explore his/her surroundings to find ways to hide effectively. Thus, the game invites the player to visit London from a global and local perspective. The player will thus map the city, visit the main buildings, travel through the city and visit anonymous houses or flats to accomplish his/her objectives. Adopting the stance of a tourist is therefore rewarding.

The immersion of the player in the Victorian city is reinforced by the graphic quality of the game. The technical progress achieved by video games over the past two decades has enabled them to represent anything in a credible fashion. This is certainly true in the case of buildings where current day screen resolutions enable artists to depict the models of buildings realistically. Allied to the different mechanisms that let players explore their gameworlds both horizontally (on the ground and through the different neighbourhoods of London) and vertically (from the underground sewers to the chimney tops). The first means to travel is the free climb up and climb down action sets which are directly inspired from parkour. The second means is the rope launcher that is unlocked at a later stage in the game and bestowed to the player by Alexander Graham Bell, a character named after the famous inventor, born in 1847, who purportedly created the first telephone; the launcher essentially functions as a grappling hook and enables the player to move easily from one roof to another without having to climb down then up again. The rope launcher also allows the player to climb buildings significantly faster than with the usual free climb up mechanism.

The combination of realistic graphics and easy ways to explore the world makes it possible for the player of Assassin's Creed Syndicate to visit Victorian London in ways that would not be possible even if he/she had been there. Within only two hours after having started the game, it is possible to climb buildings such as Big Ben, the Houses of Parliament, Admiral's Nelson's Column or even Buckingham Palace. The development team behind the game put impressive efforts to faithfully and realistically render the historical buildings, placing the player in the position of an ethnographer. During his/ her climbing or exploratory activities, the player can actively examine the details of the rendition of the buildings while he or she tries to find efficient ways to climb them. Once again, the gameplay (the climbing) is dependent on the adoption of an acute observatory attitude by the player. 
Figure 6: A look at the top of the Houses of Parliament from Big Ben

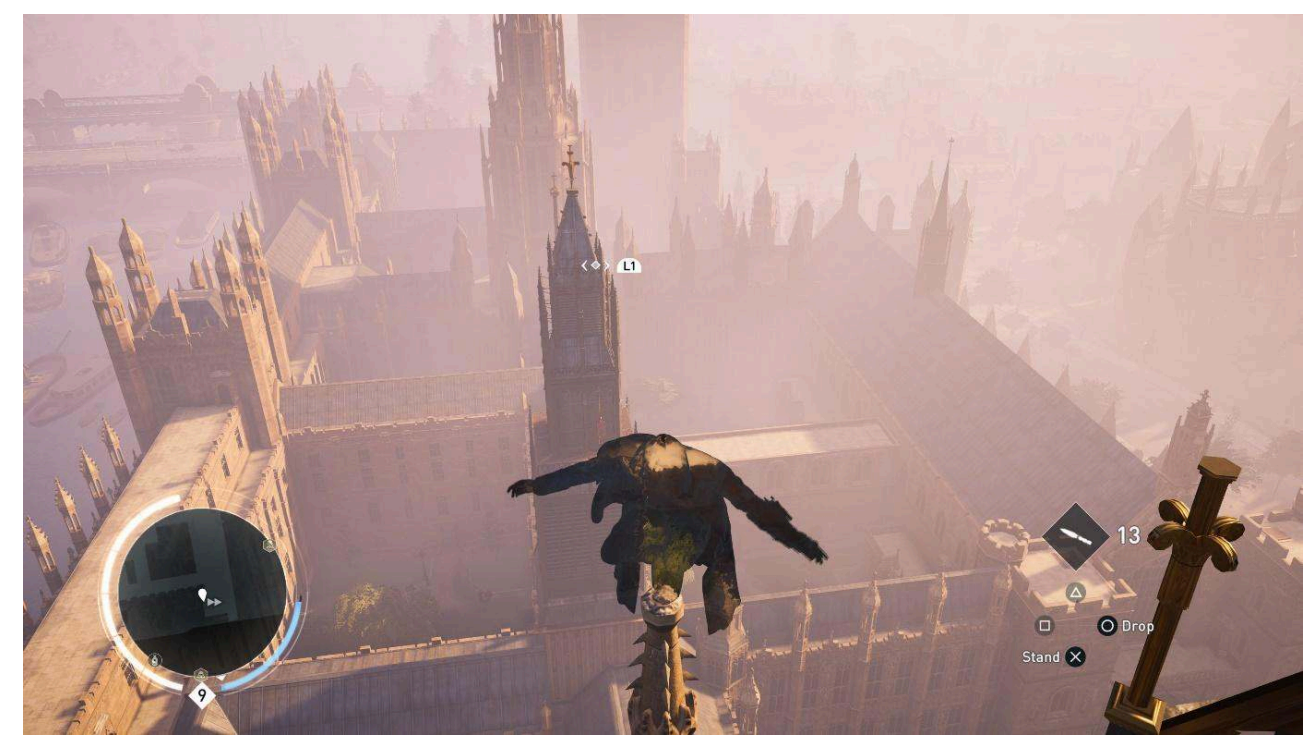

Credits: Assassin's Creed Syndicate, Ubisoft. with his voice-over, commenting on every detail of the city: from the padding of the carriages in the street, to the gas lamps, through the typical iron and glass coverings of the market places. He also evokes and shows in-game the north-south division of London, with the industrial south and its sawmills, factories, black smoke rising from the chimneys, the windmills and the streets of mud with ranges of houses and yards stuck to each other with barely room to walk among the mess, described by Friedrich Engels in his essay on The Condition of the Working Class in Victorian Times (Engels 1892). The city is divided into seven areas (The Strand, The Thames, The City of London, Westminster, Whitechapel, Lambeth and Southward), each divided into sub-areas. The Thames, crowded with boats, occupies a central position in the game, reflecting its central position in the real city and in the history of London (Figure 7). The north of the city in the game also reflects this class division with richer neighbourhoods, nicer houses, larger and cleaner streets (Figures 8-9). 
Figure 7: The crowded Thames

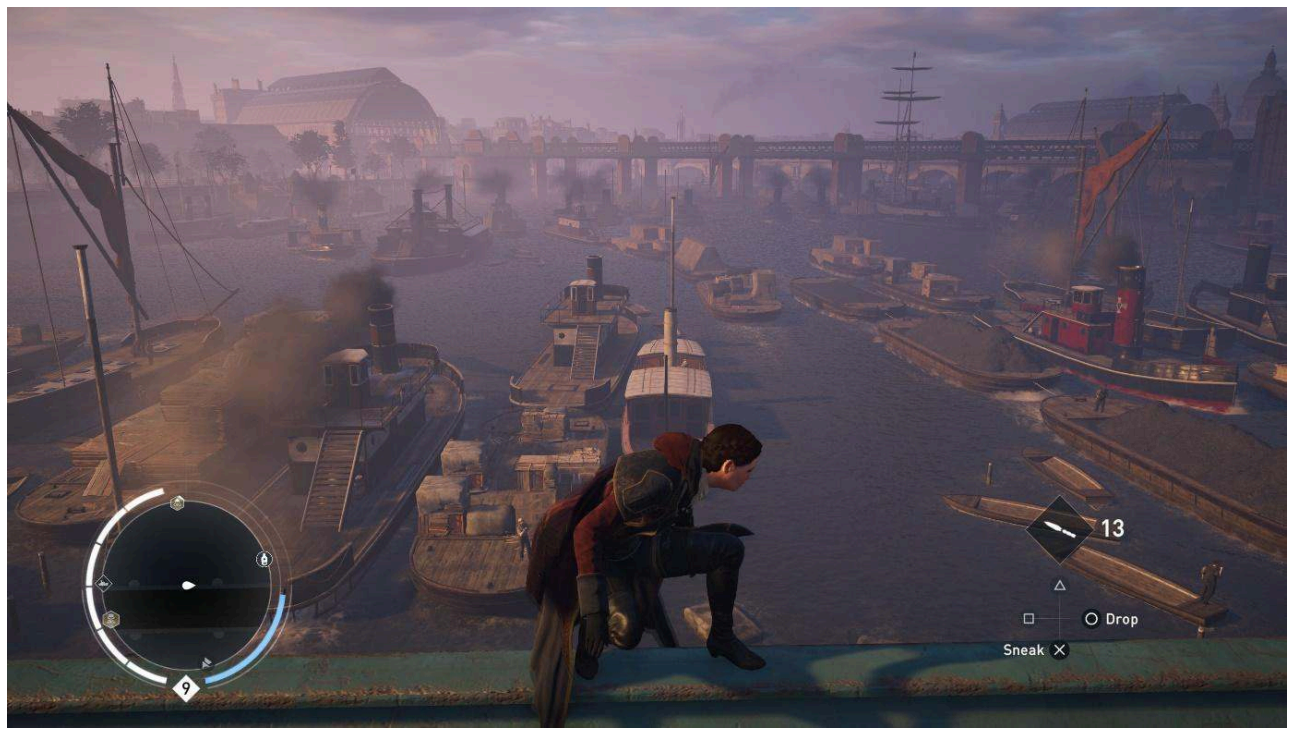

Credits: Assassin's Creed Syndicate, Ubisoft.

Figure 8: A street from the northern part of London

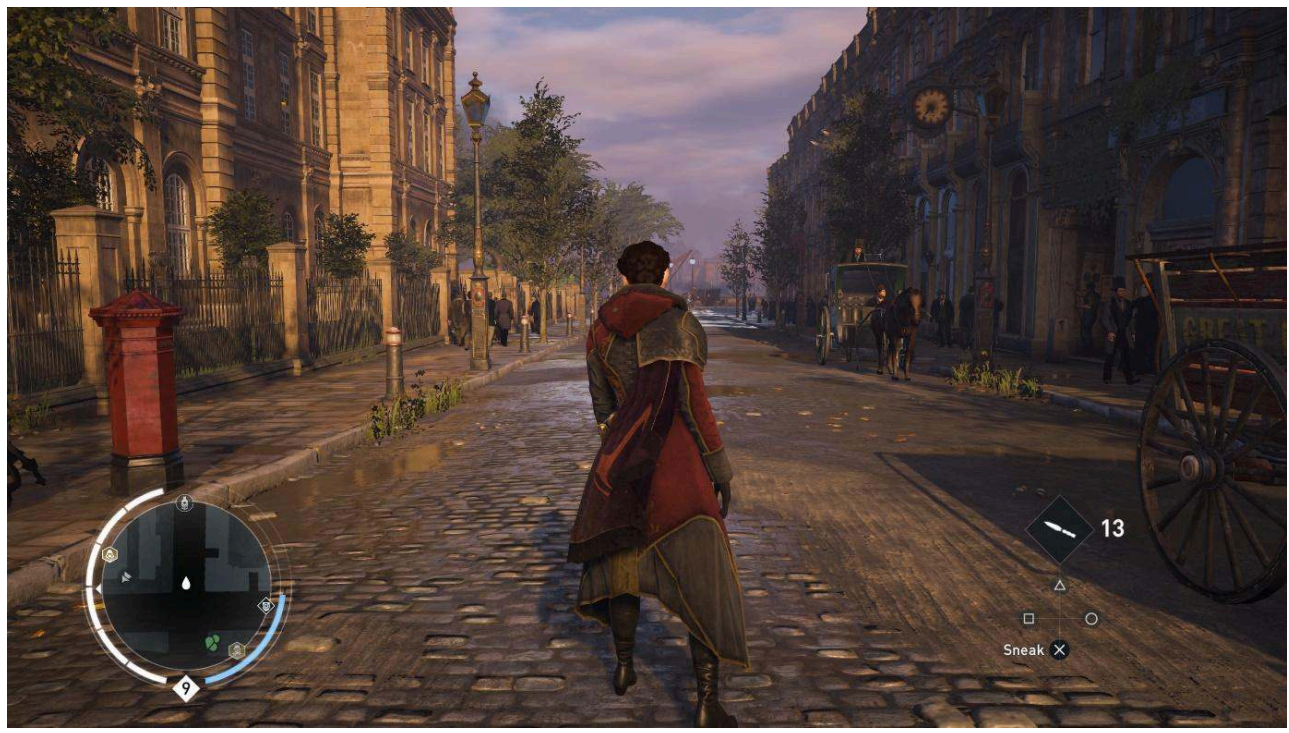

Credits: Assassin's Creed Syndicate, Ubisoft. 
Figure 9: A street from the southern part of London

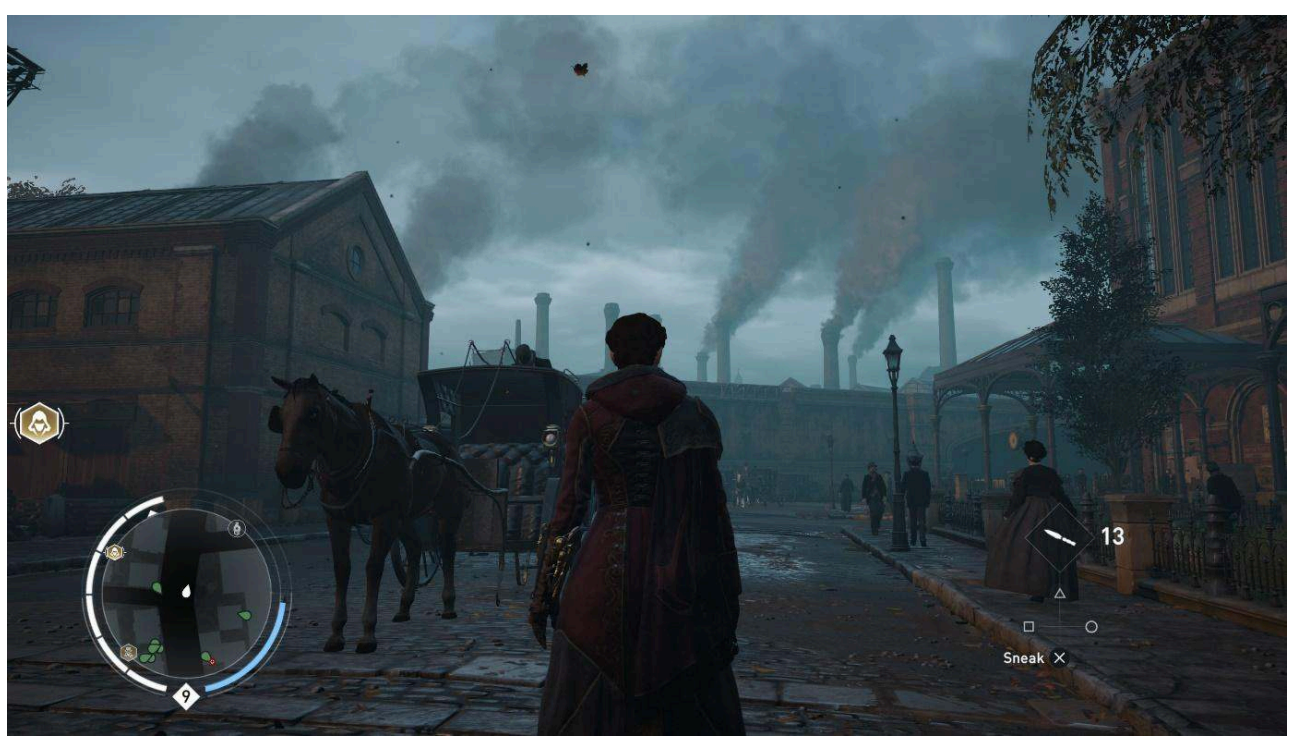

Credits: Assassin's Creed Syndicate, Ubisoft. academic writer), Jean-Vincent Roy, to document the Victorian city in order to help the game artists render a city faithful to the original. Roy explored archives and made several field trips to get a sense of the city, and collaborated with Judith Flanders, a senior research fellow in $19^{\text {th }}$-century social history (Sapieha 2015). Nevertheless, Roy kept in mind that the rendition of 1868 London needed to be considered from the perspective of the game. Assassin's Creed is a video game franchise where not only exploration but also action are at the core of its gameplay. The series became famous because of its parkour mechanisms which allow the player to make his/her character climb and jump to almost anything realistically usable and within his/her reach. To do this, Roy could not work on an authentic rendition of the city, but rather on a gameworld that offers the player "a highly authentic impression of London" (Sapieha 2015, my emphasis). Thus, the landmarks in-game are to scale and highly faithful to their originals, but their distances from each other are shorter.

The tourist's stance that the game incites the player to take culminated in the series in an episode in Assassin's Creed Origins which takes place in ancient Egypt, with the addition of a discovery tour mode. This game mode is defined by the editor as a "new educational mode" enabling the player to "dive into the history of the ancient world with 75 interactive tours". This game mode lets the player re-experience the gameworld, in this case Alexandria and its surroundings, but without the dangers and objectives of the main game. The creative director of Assassin's Creed Origins, Jean Guesdon, explained in a promotional trailer that "all of a sudden you're not in the game anymore, you're just in Egypt, enjoying it and looking at the world like never before" (see video below).

This media file cannot be displayed. Please refer to the online document http:// journals.openedition.org/angles/2818

31 The discovery tour is not a full documentary and contains adapted history. Over the past few years, Ubisoft has been trying to push a progressive agenda, and since 2015 the 
games of the Assassin's Creed franchise load with a text written on a black screen stating: "Inspired by historical events and characters, this work of fiction was designed, developed, and produced by a multicultural team of various beliefs, sexual orientations and gender identities." This text serves to remind the player that the gameworld remains a world of fiction and the discovery tour contains falsified elements to fit that agenda. For example, in Assassin's Creed Odyssey, a vase depicting children going to school in Ancient Greece was modified to include girls to make the game and its gameworld more inclusive (Figure 10). As such, the 'discovery tour' should not be taken at face value.

Figure 10: A 'behind the scenes' inclusive entry from Assassin's Creed Odyssey

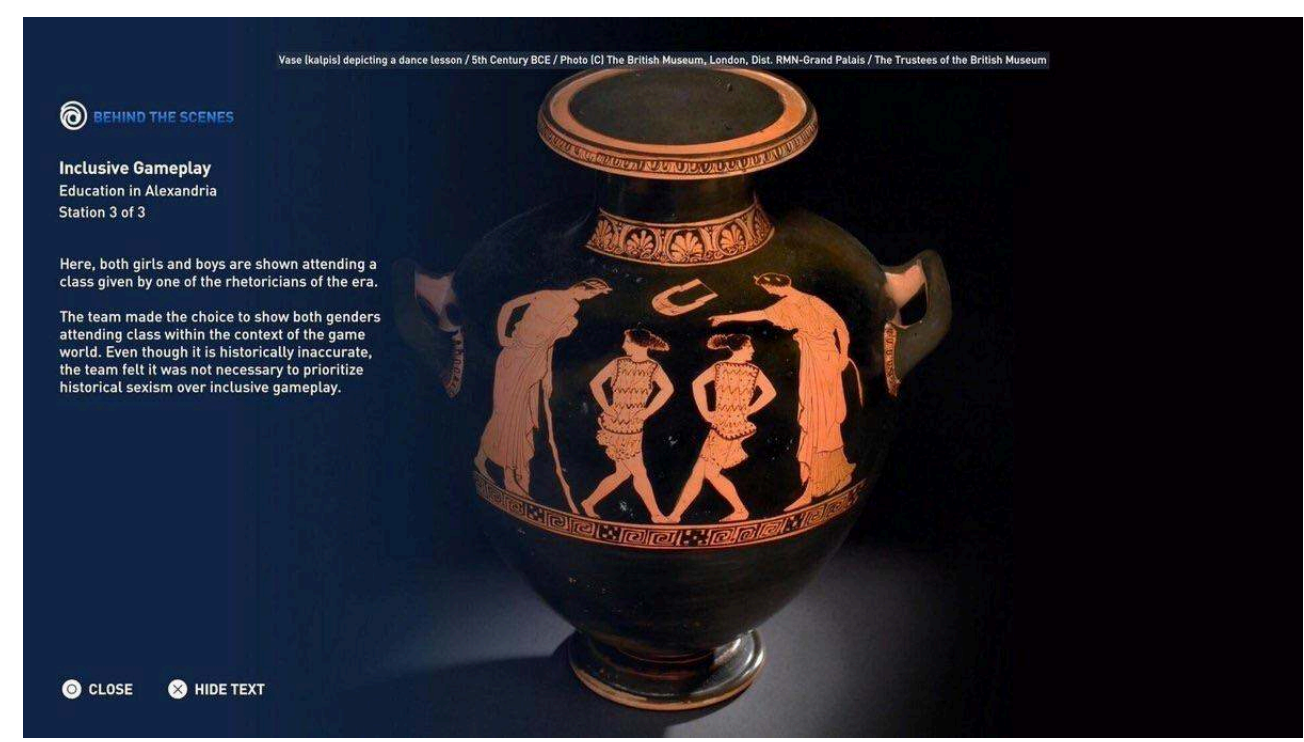

This example shows how history is sometimes adapted to fit the game's political message of inclusivity.

Credits: Assassin's Creed Odyssey, Ubisoft.

For Evelyn Ferron, a history lecturer on documentary methodology at Sherbrooke University who acted as a consultant for the creation of the discovery tour mode of the episode Assassin's Creed Origins: "Students [...] will remember more what we teach if they can feel it" (Ubisoft North America 2018) - an assertion made not in an academic article but in a promotional video for the game. Nevertheless, the use of the word "feel" is revealing because that is what Jean-Vincent Roy intended to do with Assassin's Creed Syndicate, i.e. to have the player feel as if he or she were in 1868 London, making this fictional London credible, if entirely accurate. In Assassin's Creed Syndicate, there was no 'discovery mode', but the game does offer an Encyclopedia of the places visited (Figure 11) as well as of the people of Victorian London met there, providing anecdotes about both. 
Figure 11: The in-game article for Lambeth Palace

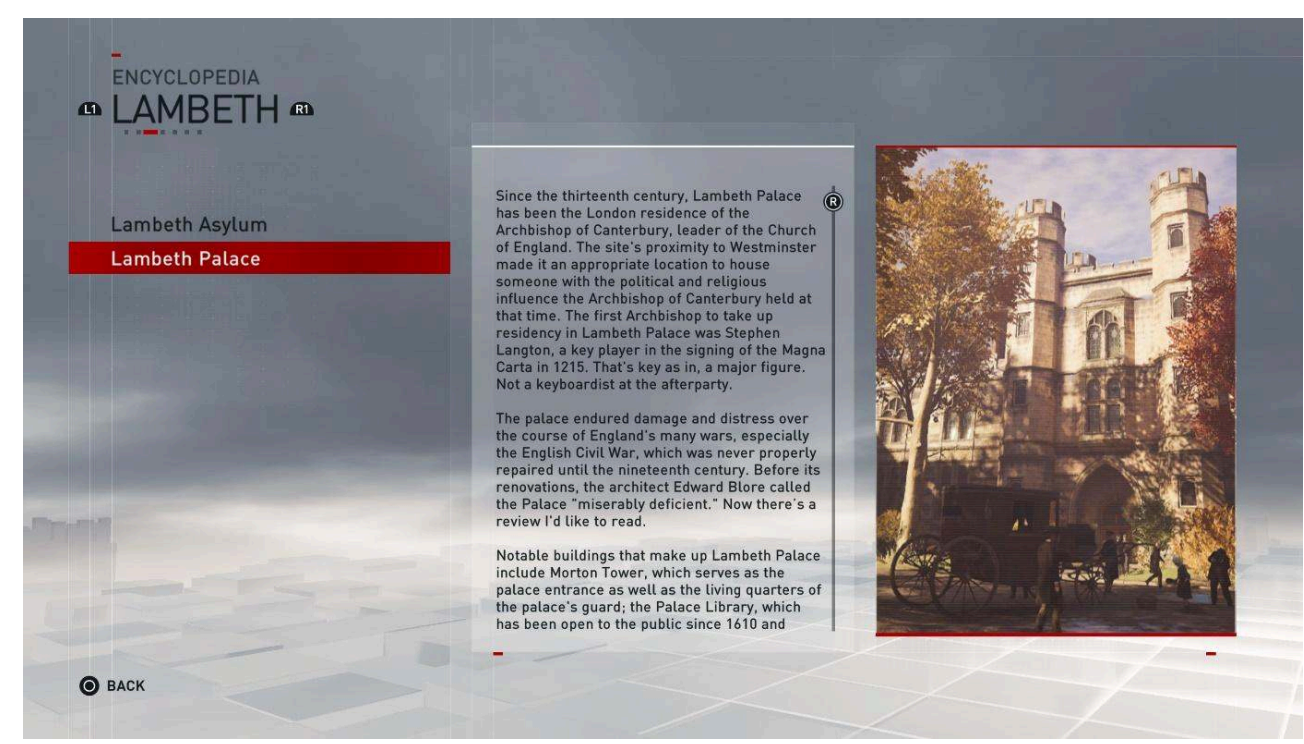

Credits: Assassin's Creed Syndicate, Ubisoft. of real historical characters: Alexander Graham Bell, Karl Marx, Charles Darwin, Benjamin Disraeli, James Brudenell, Queen Victoria, Charles Dickens and Florence Nightingale all make appearances. This roster of characters sums up the period thematically; it is not just occupying filler positions. Alexander Graham Bell, Charles Darwin and Florence Nightingale represent the scientific achievements of the United Kingdom in the four main scientific fields: physics for Bell, biology for Darwin, and mathematics and medicine for Nightingale (Figure 12). Charles Dickens, Karl Marx, Florence Nightingale and Benjamin Disraeli represent politics and the need for reform: Dickens through the arts and his interests; Marx through his sociology, philosophy and activism; Nightingale through pragmatic measures and the emergence of women's 
liberation movements; and Disraeli who represents social change through parliamentary activity. The strength and the reach of the British Empire are embodied in Benjamin Disraeli for the political aspect, the Queen for the imperial one, and James Brudenell for its military might.

Figure 12: The in-game encyclopedia entry for Florence Nightingale and her model

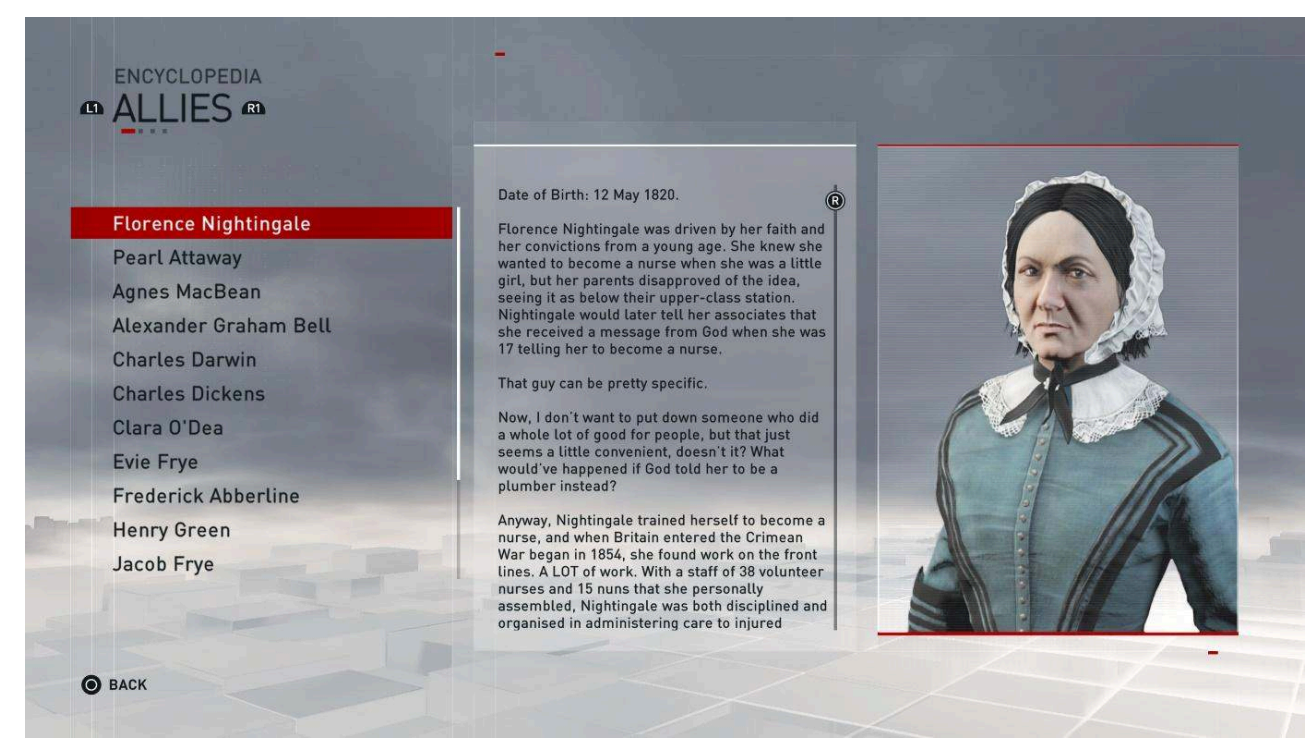

Credits: Assassin's Creed Syndicate, Ubisoft.

The crowd also plays its role in the immersion of the player. The developers of the game made great efforts in building the fictional world so that the population seems lively. As explained by Jonathan Dumont, the game's world director:

At night the crowd doesn't do the same things it does during the day. We've tried to make it a living ecosystem. Aside from major markets that could be open day or night, you won't see many merchants at night. Areas where people go to work during the day, like the financial district, are a lot emptier at night. At a pub you'll see people having a beer during the day, but at night it's a party in there. It makes it more credible. (Sapieha 2015)

The crowds wandering about in Assassin's Creed Syndicate are not inactive, the player can follow non-player characters in the city and watch them live little slices of their lives. Some of these characters are directly linked to some short-term objectives ingame; some missions involve liberating child labourers from evil factory managers, for instance. This is put in context in-game: the children carry out repetitive tasks like assembling small screws or sweeping the floor, they are pictured as dirty and very thin, poorly clothed and often subjected to beatings and violence by adults in factories. If the player wanders around these factories, one can see the children being brought in by child traffickers.

Assassin's Creed Syndicate can be summed up as a historically set game. A great deal of realism emerges from it and gives birth to a credible adaptation of its historical and geographic setting. The city offers not only a realistic environment but uses this to contribute to its gameplay, making the Victorian setting an integral part of the mechanics of the game. 


\section{Conclusion: Two Models of Incorporation of History into Video Games}

39 The different genres of the two games studied in this article may have preconditioned the way in which they incorporate history. Assassin's Creed Syndicate is more oriented towards free roaming among the city, and naturally invites the developer to fill its setting with elements to make it interesting and not repetitive. Ubisoft made the choice of realism by inviting and even recruiting historians to make its city as believable as possible. Importantly, Jean-Vincent Roy had previous experience in the video game development field and had knowledge about what made a game interesting and fun to play, and his work as a historian was made in close cooperation with the world development team that took part in Roy's research on Victorian London (Sapieha 2015). The game set aside "grand history," using only parts of it. Instead, it relied more on city's details, making the game use history but also show pieces of history to its players through the feeling that one explores the city in the position of an anthropologist, inciting players to be curious about their environment. The game's faithfulness to history is strong and was praised by professional historians. With the integration of the setting into the gameplay I described above, the Victorian setting was made an integral part of the game on an organic and thematic level.

Conversely, The Order 1886 fails in this regard: it only uses Victorian London as a backdrop whose sole purpose is to generate an atmosphere of anxiety. Any other gloomy setting could have produced the same effect on the player. The genre of the game and its linearity might not be the cause of its failure to exploit the Victorian setting. Many games function in a very directive way, offering little more than corridors to visit, but usually compensate this narrow perspective by offering rich details to their players though dialogue, information and a long-developed story (Simons 2007). It seems the failings of The Order 1886 to exploit the Victorian stem from its failure as a game. One popular and knowledgeable French game-streamer described the game as " $50 \%$ movie, $40 \%$ QTEs and $10 \%$ game" and as "Netflix: the game" (BenzaieLive 2015). The lack of 'gameness' seems to be a consensus among negative critics: the story is told in the manner of a film. If the player tries to walk too fast in a corridor, he/she will be stuck until the dialogue heard in the background is over. The lack of interaction and responsiveness more often than not incites the player to drop his/her controller on the couch, waiting for the scene to solve itself on its own.

41 Assassin's Creed Syndicate will appeal to historians and can trigger interest in, as well as educate on, Victorian London, creating fruitful debates on the fidelity of its transposition from game to reality. In contrast, The Order 1886 will only appeal to people who appreciate not Victorian society, but steampunk aesthetics inspired by Victorian times. The game teaches the player almost nothing about its times and offers no device to trigger the interest of the players in their surroundings. Another element that contributes to the gap in cultural content between the two games is their length. The average time of completion by the players recorded on the website howlongtobeat.com for Assassin's Creed Syndicate while doing a few extra missions at a leisurely pace is an impressive 67 hours and 38 minutes. The same measure applied to The Order 1886 indicates a completion time of only 13 hours and 20 minutes.

The Victorian setting is a rich one which has often triggered the interest of game developers, but its transposition into an effective and successful in-game use is 
complicated and requires much forethought. It is easy to fall prey to a thematic approach to a certain setting. The Order 1886 draws much inspiration from movies, to the point it fails to use the full possibilities offered to video games. The success of Assassin's Creed Syndicate in exploiting its historical setting compared to other games seems to be the consequence of its better understanding its own medium; it plays with history and let gamers play in history (Marti 2018). The different approaches of the two games can be modeled below:

Table : Synthesis of the two models of historical games

\begin{tabular}{|c|c|c|c|c|}
\hline $\begin{array}{l}\text { Disciplinary } \\
\text { Field }\end{array}$ & Element & $\begin{array}{ll}\text { The } & \text { Order } \\
1886 & \end{array}$ & $\begin{array}{l}\text { Assassin's Creed } \\
\text { Syndicate }\end{array}$ & Explanation \\
\hline \multirow{2}{*}{ Narration } & Diegesis & Simple & Complex & $\begin{array}{l}\text { Form of narration (place/ } \\
\text { focalisation/time) }\end{array}$ \\
\hline & Linearity & Linear & Non linear & $\begin{array}{l}\text { Is the player free to decide } \\
\text { what he/she does? }\end{array}$ \\
\hline Anthropology & Approach & Observant & Participant & $\begin{array}{l}\text { Can the player interact freely } \\
\text { with his/her environment? }\end{array}$ \\
\hline \multirow{4}{*}{ Game Design } & Camera & $\begin{array}{l}\text { Free camera } \\
\text { Close to } \\
\text { character }\end{array}$ & $\begin{array}{l}\text { Free camera } \\
\text { Variable distance }\end{array}$ & $\begin{array}{l}\text { How does the camera move } \\
\text { around the character? }\end{array}$ \\
\hline & Gameplay & $\begin{array}{l}\text { Fully } \\
\text { scripted }\end{array}$ & Emergent & $\begin{array}{l}\text { Is the player allowed to choose } \\
\text { how to resolve the problems } \\
\text { he/she faces? }\end{array}$ \\
\hline & Cutscenes & $\begin{array}{l}\text { Numerous } \\
\text { and long }\end{array}$ & Few and short & $\begin{array}{l}\text { Presence of cinematic } \\
\text { moments of "non game" }\end{array}$ \\
\hline & Graphics & $\begin{array}{l}\text { Very } \\
\text { realistic }\end{array}$ & Realistic & Quality of the graphics \\
\hline \multirow{3}{*}{ History } & Faithfulness & Non & Seemingly faithful & Feeling of authenticity \\
\hline & $\begin{array}{l}\text { Elements of } \\
\text { reality }\end{array}$ & Scarce & Numerous & $\begin{array}{l}\text { Presence of non-fictional } \\
\text { elements (characters, works of } \\
\text { art, locations) }\end{array}$ \\
\hline & $\begin{array}{l}\text { Model of } \\
\text { approach }\end{array}$ & Filmic & $\begin{array}{l}\text { Ludo- } \\
\text { anthropological }\end{array}$ & \\
\hline
\end{tabular}

The immersive models of the two games show how the player will integrate the historical setting to their gaming practice. The Order 1886 responds to a filmic approach, where the experience is presented to the player in a certain predetermined form. This approach will result in a similar experience for all players; freedom is sacrificed for a 
more controlling type of storytelling. As such, the game uses a fictional rendition of history to create another space. The immersion is drawn from the filmic techniques employed rather than a seemingly faithful rendition of Victorian London. What is taken from history is only what could serve the fictional aspect of the game even if it means rewriting it. Assassin's Creed capitalizes on a historical and anthropological approach to let the player experience London by being able to interact with it. As shown above, London is part of the gameplay rather than just part of the setting. As a result, The Order 1886 will require its player to adopt the stance of a game-movie spectator while Assassin's Creed Syndicate will require him/her to adopt the stance of a gameethnographer. In this respect, video games could fulfil methodological objectives akin to role playing games used in anthropology classes. Susanne Kuehling (University of Regina) has thus developed a role-playing game with her students in which they play the roles of islanders. Through her experiments, the professor observed that:

As members of The Tribe, students can feel like owners of their knowledge as they are at once authors, performers and audiences. As author, the student has the opportunity to script the action; as performer, he/she must deal with the consequences of this script as well as unforeseen developments; and as audience, he/she observes and reflects upon the unfolding action. This synergy, according to recent studies on educative computer-based simulation games, "yields a dynamic set of positioning with the potential to simultaneously establish a narrative and convey a lesson, all in a manner that grants the player involvement, ownership, and responsibility". (Kuehling 2014)

Games which are rich in content often give birth to wikias or wikis, i.e. sites created under the model of Wikipedia thanks to a standardized model created through the site https://www.fandom.com/. To this day, thousands of collaborative gameencyclopedias have produced lengthy articles about in-game characters, places, concepts written and documented by the players themselves. The collaborative nature of these articles makes the players who want to contribute take up the role of encyclopedists, or researchers. To write these articles, players explore the gameworld meticulously and search information through other sources to document their findings (Figure 13). 
Figure 13: A screenshot of the article for Benjamin Disraeli in the Wikia for Assassin's Creed Syndicate

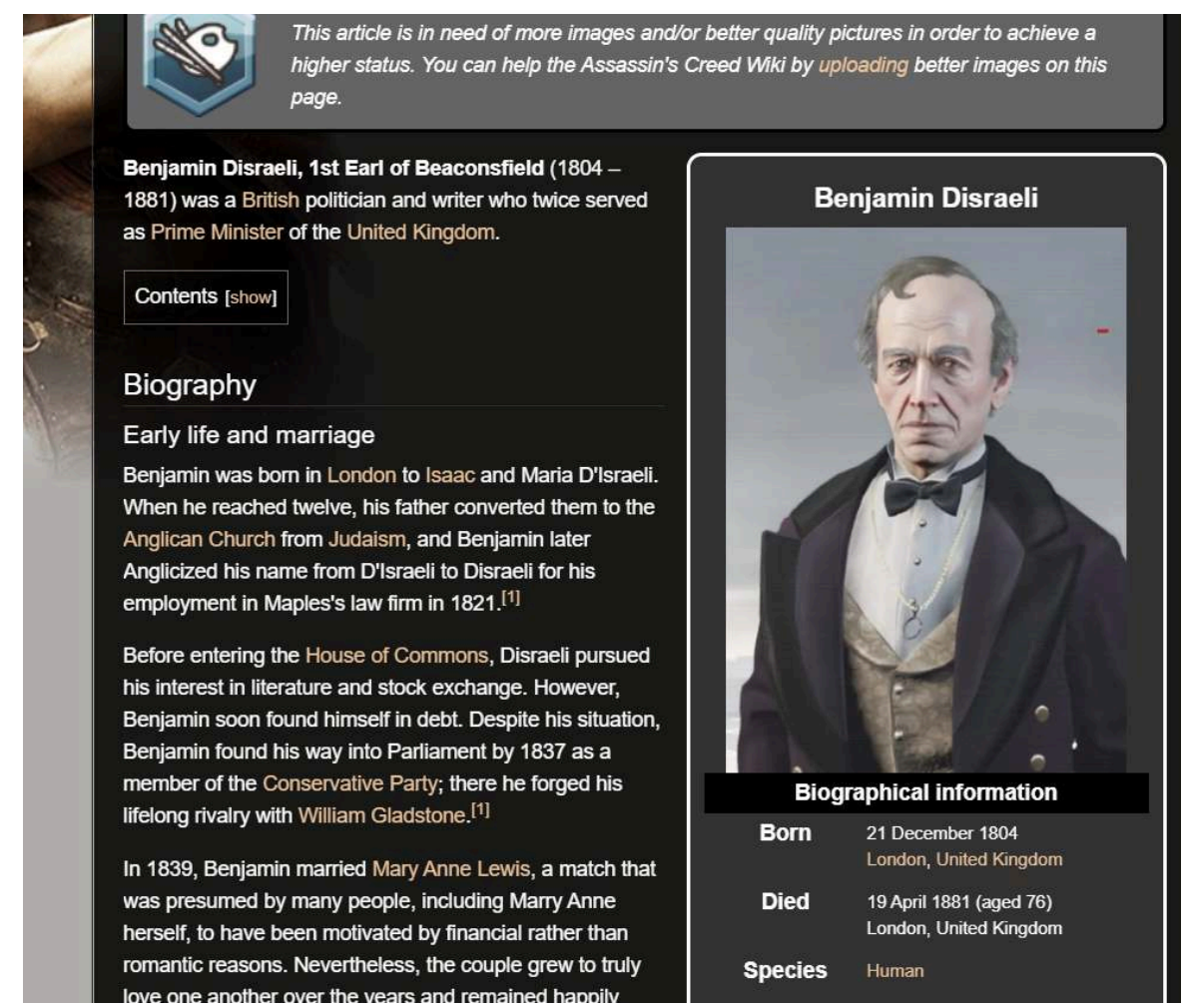

Credits: https://assassinscreed.fandom.com/wiki/Assassin\%27s_Creed:_Syndicate

Such documentary efforts concerning the space in which the player evolves can result in a virtuous circle of involvement both in the game and in side-related research that could be summed up as follows:

Table : The virtuous cycle resulting from anthropological approaches to video games

Wiki pages have their limitations, but they teach players to document their experiences of the gameworld and how to source their data. Occasionally, academic works are listed among the references of articles (Figure 14), showing the proto-academic nature of this type of game. The centralisation of data makes it easy even for a player with no specific methodological training to retrieve information on the setting of the game he/she plays, resulting in a pedagogical experience through browsing an encyclopedia and a more intellectual involvement in his/her game. 
Figure 14: A screenshot of the list of references for the London article in the Wikia for Assassin's Creed Syndicate

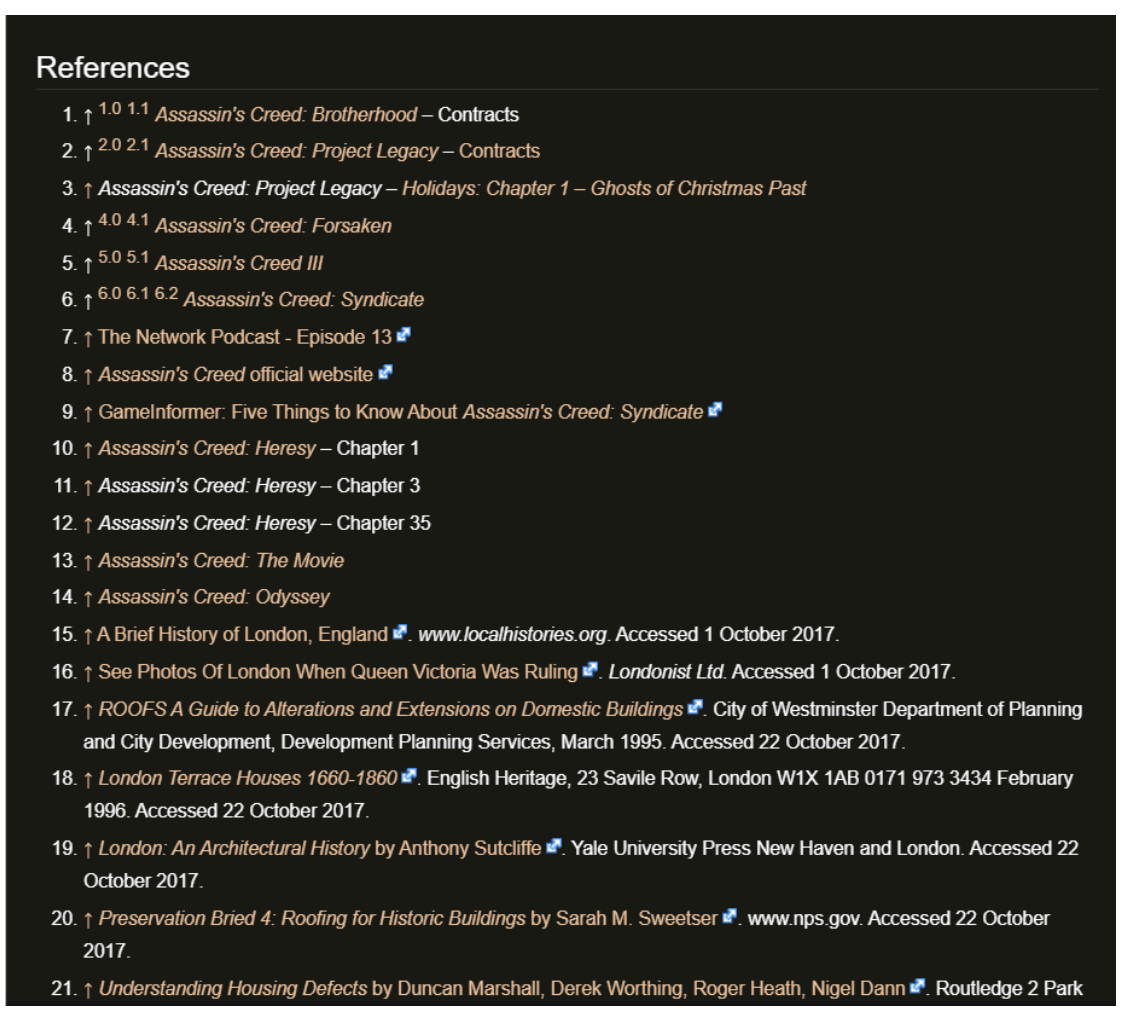

Credits: https://assassinscreed.fandom.com/wiki/London

The success of Assassin's Creed Syndicate in incorporating the Victorian setting to its gameplay proves that a transdisciplinary approach to game design, at the crossroads of history, ludo-narratology, and anthropology could be beneficial to all aspects of a game, from a technical, commercial, scientific and educational perspective.

\section{BIBLIOGRAPHY}

\section{Texts}

Byrd, Christopher. "The Order: 1886 reviewed - A beautiful, boring disappointment.” The Washington Post, 23 February 2015. https://www.washingtonpost.com/news/comic-riffs/wp/ 2015/02/23/the-order-1886-reviewed-a-beautiful-boring-disappointment/

Engels, Friedrich. The Condition of the Working Class in England. London: Penguin, [1892] 2005.

Karsenti, Thierry. “Can students learn history by playing Assassin's Creed?” Montreal: CRIFPE, 2019. http://www.karsenti.ca/Assassins_creed_Report_EN.pdf 
Kuehling, Susanne. "Transforming classrooms into tropical islands: simulation as a teaching tool”. Teaching Anthropology: a Journal of the Royal Anthropological Institute 4 (2014). DOI: 10.22582/ ta.v4i1.259

Marti, Marc. "L'Histoire dans le Jeu Vidéo, une Généalogie Narrative Problématique ? Le Cas de la Guerre d'Espagne (1936-1939) et de sa Ludicisation." Science du Jeu 9 (2018). DOI: 10.4000/sdj.1041

Miller, Kiri. “The Accidental Carjack: Ethnography, Gameworld Tourism, and Grand Theft Auto.” Game Studies: International Journal of Computer Game Research 8:1 (2008). http://gamestudies.org/ 0801/articles/miller

Nielsen, Holly. "Reductive, superficial, beautiful - a historian's view of Assassin's Creed: Syndicate". The Guardian, 9 December 2015. https://www.theguardian.com/technology/2015/dec/09/ assassins-creed-syndicate-historian-ubisoft

O'Rourke, Patrick. “The Order 1886's Creative Director on Why the Game has no Multiplayer and Why he Insists it isn't Steampunk.” The Financial Post, 11 December 2014. https:// business.financialpost.com/technology/gaming/the-order-1886s-creative-director-on-why-thegame-has-no-multiplayer-and-why-he-insists-it-isnt-steampunk

Sapieha, Chad. "How historians and artists crafted a 'highly authentic impression' of London for Assassin's Creed Syndicate." The Financial Post, 20 October 2015. https://business.financialpost.com/ technology/gaming/how-historians-and-artists-crafted-a-highly-authentic-impression-oflondon-for-assassins-creed-syndicate

Schweighauser, Philipp. "Doubly Real: Game Studies and Literary Anthropology; or, Why We Play Games." Eludamos. Journal for Computer Game Culture 3:2 (2009): 115-32. https:// www.eludamos.org/index.php/eludamos/article/view/vol3no2-1/121

Simons, Jan. "Narrative, Games, and Theory." Game Studies: International Journal of Computer Game Research 7:1 (2007). http://gamestudies.org/07010701/articles/simons

Vandermeer, Jeff. The Steampunk Bible: an Illustrated Guide to the World of Imaginary Airships, Corsets and Goggles, Mad Scientists, and Strange Literature. New York: Abrams Image, 2011.

Von Lunen A., KJ. Lewis, B. Litherland and P. Cullum (eds.). Historia Ludens: The Playing Historian. Abingdon \& New York: Routledge Taylor \& Francis Group, 2019.

\section{Games}

Assassin's Creed Syndicate. Ubisoft. 2015.

The Order 1886. Ready At Dawn. 2015.

\section{Videos}

Ubisoft North America, Assassin's Creed Discovery Tour | Trailer | Ubisoft [NA]. https:// www.youtube.com/watch?v=_yMDdQKfv70.

BenzaieLive. The Order 1886 \#2 - Netflix The Game - Stream du Verdict - Benzaie. https:// www.youtube.com/watch?v=ZvuBNw4U8kg.

BenzaieLive. The Order 1886 \#3 - 50\% film 40\% QTE 10\% Jeu - Stream du Verdict. https:// www.youtube.com/watch?v=Saf8dzls7xQ. 
Leematthewjackson. Assassin's Creed Syndicate - Looking at Victorian London. https:// www.youtube.com/watch?v=EPGa6nCcViQ\&t.

Checkpoint TV. Assassins Creed Syndicate - Interview with the historian Lee Jackson. https:// www.youtube.com/watch?v=iXe98pxa9EM.

\section{Others}

Assassin's Creed Syndicate Wikia page. https://assassinscreed.fandom.com/wiki/

Assassin\%27s_Creed:_Syndicate

\section{NOTES}

1. Metacritic is a website that aggregates reviews of video games. The metacritic score is made up of the average of the grades given to the game in the specialized press around the world.

\section{ABSTRACTS}

Historical games deserve to be examined not only by video games academics but by cultural studies academics. The environments in which historical games are set, and how their gameplay and game design allow the players to explore them, give new opportunities to the public to learn about history. Furthermore, the excitement and interest players have for locales has reached the point where a "tourism/educational mode" has been added in the Assassin's Creed games series, allowing them to freely explore ancient Egypt (Assassin's Creed Origins) and Greece (Assassin's Creed Odyssey). This mode features information about historical monuments recorded by academics, which allows players to learn about the environment. Interestingly enough, industrial Britain and especially Victorian Britain have often been chosen as a setting for numerous games. This paper compares the representations of Victorian Britain in two games. The first is Assassin's Creed Syndicate, a game in which one plays an assassin in a realistic representation of Victorian Britain; the second is The Order 1886, a game set in a fictitious alternative world in 1886 in which one plays Knights of the Round Table fighting against gothic-themed creatures such as werewolves and vampires in a steampunk setting. Examining historical representations in fiction is interesting, but video games bring a new component to the experience compared to other media, as they let players create their own experience and narrative interactively. Gaming can thus be considered a worthwhile cultural practice because it succeeds in giving history subjective, sensory and experimental dimensions that other media lack. It enables the player to play in history as much as playing with it, sometimes giving the player an anthropological stance. In this respect, Assassin's Creed stands as a successful adaptation of the Victorian context because it manages to integrate its historical setting into its gameplay mechanics, while The Order 1886 only uses it as a cardboard setting with limited interest to the game itself. This article attempts to create a system by comparing the two games, presenting new means of analysis of the use of history in video games. 
Les jeux vidéo historiques permettent aux joueurs de visiter des environnements auxquels il leur est impossible d'avoir accès dans la vie réelle, de cette manière ils fournissent de nouvelles possibilités pour le grand public d'explorer l'Histoire de l'humanité. L'intérêt suscité par cet aspect particulier du jeu vidéo a abouti récemment en la création d'un mode « tour » dans les jeux de la franchise Assassin's Creed. Ce mode éducatif permet alors aux joueurs d'explorer librement l'Egypte antique (dans Assassin's Creed Origins) et la Grèce antique (dans Assassin's Creed Odyssey). Ce mode de jeu inclut des commentaires écrits et enregistrés par des universitaires, ce qui permet à son public d'en apprendre plus sur l'environnement dans lequel leur avatar virtuel évolue. De son côté, la Grande-Bretagne victorienne a connu également son lot d'adaptations vidéoludiques. Cet article compare la représentation de la Grande-Bretagne victorienne dans deux jeux en explorant à la fois l'intérêt de sa représentation d'un point de vue vidéoludique et ethnographique. Le premier jeu étudié, Assassin's Creed Syndicate, propose au joueur d'incarner des membres d'une confrérie secrète d'assassins dans une représentation réaliste du Londres des années 1840. Dans le second jeu, The Order 1886, le joueur joue un chevalier de la table ronde affrontant des créatures issues de l'imaginaire gothique (des loups-garous ou des vampires) dans un univers steampunk. Si l'étude des représentations de lieux historiques dans des univers fictionnels est intéressant, la nature expérientielle du jeu vidéo permet à son public d'approcher l'histoire d'une manière unique, laissant ses joueurs créer leur propre approche d'univers de manière interactive. La pratique du jeu vidéo peut alors être considérée comme une pratique culturelle à part entière car elle permet de fournir à l'histoire une dimension subjective, sensorielle et expérientielle qui ne peut être fournie par aucun autre media. Les jeux vidéo permettent ainsi aux joueurs de jouer au sein de l'histoire mais également de jouer avec l'histoire même, en initiant, par leur nature, le joueur à une pratique anthropologique. A ce titre nous examinerons comment Assassin's Creed réussit à adapter le contexte particulier du Londres victorien par sa capacité à intégrer son univers contextuel dans ses mécaniques de gameplay, là où The Order 1886 n'utilise l'univers victorien que comme décor unidimensionnel. Cet article développe, enfin, un système de comparaison proposant de nouvelles pistes d'études pour l'analyse des usages de l'histoire dans les jeux vidéo.

\section{INDEX}

Mots-clés: jeux vidéo, Assassin's Creed, Order (The), Ubisoft, Ready at Dawn, jeux historiques, ludo-narratologie, narratologie, anthropologie, jeux, londres, epoque victorienne, steampunk, néo-victoriannisme, ethnographie

Keywords: video games, Assassin's Creed, Order (The), Ubisoft, Ready at Dawn, historical games, ludology, narratology, anthropology, gaming, Victorian London, steampunk, neo-Victorian, ethnography, games

\section{AUTHOR}

\section{NICOLAS SIGOILLOT}

Nicolas Sigoillot is a PhD candidate at Dijon University where he teaches British civilization. His main research is dedicated to the study of Marxist political groups in Britain; his secondary research field tries to establish a link between Marxist historical studies and video game studies. Contact: nicolas.sigoillot [at] u-bourgogne.fr 